\title{
Assessment of Flood Vulnerability Using Fuzzy Logic and Geographical Information Systems
}

\author{
Valentina Nikolova ${ }^{1}$ and Plamena Zlateva ${ }^{2}$ \\ ${ }^{1}$ Department of Geology and Geoinformatics, MGU, Sofia, Bulgaria \\ v.nikolova@mgu.bg \\ ${ }^{2}$ Institute of System Engineering and Robotics - BAS, Sofia, Bulgaria \\ plamzlatevalabv.bg
}

\begin{abstract}
The assessment of river flood vulnerability requires analysis of the whole physical-geographical environment, and taking into account the interaction between all natural and social-economic components of the study area. In the current paper a flood vulnerability map is elaborated in Geographical Information Systems (GIS) environment using fuzzy logic overlay analysis. Precipitation, distance from streams, flow accumulation, lithology, land use, slopes and altitude are considered and analysed as factors influencing the floods. In particular, the proposed methodology for an assessment of flood vulnerability by fuzzy logic is applied for the catchment of the river Luda Kamchia. This river is situated in the Eastern Bulgaria, Europa. It takes about 1600 square kilometers. The relief is mainly low-mountainous and the annual amount of precipitation is between 600 and $800 \mathrm{~mm}$, influenced by the Black sea in the eastern part of the river basin. Proposed methodology for the assessment of river flood vulnerability and elaboration of maps of flood vulnerability by fuzzy logic overlay analysis in GIS environment is a first step in development of the information system for integrated risk assessment from natural disasters.
\end{abstract}

Keywords: River Flood Vulnerability, GIS, Overlay Analysis, Fuzzy Logic.

\section{$1 \quad$ Introduction}

The increasing cases of river floods in global scale and damages caused by them determine the importance of the problem. For these reasons, it is need for more detailed study of the floods factors. The floods are one of the most widespread natural disasters with natural and social components. The assessment of flood vulnerability requires analysis of the completely physical-geographical environment and taking into account the interaction between all natural components of the area [1]. Social and economic infrastructures also should be taken in consideration, particularly in flood risk assessment and mitigation. A large amount of quantitative data about river runoff, precipitation, river basin hydrological and morphometric features have to be processed. The interpretation of available data and analysis of hydro-climatic factors of floods are in relation of lithology, soils, relief and land use of the river basin. In this regard, the used methods in investigation of river flood susceptibility could be divided in the three 
groups: mathematic-statistical; geographical-spatial analysis and modelling. The use of GIS technology allows processing of large amounts of data and optimization of the decision-making process [2]. The application of remote sensing gives information as about difficult accessible areas as well as about large areas and could be shortened the research time.

There are many researches about flood susceptibility, flood vulnerability/ hazard and risk assessment using GIS and remote sensing [3, 4]. The development of technology and seeking more detailed investigation of flood parameters, even in areas that are difficult to access, determine developing of the research of flood susceptibility, flood hazard and risk, and wider application of remote sensing methods and GIS [5-7].

Different floods influencing factors are considered in the publications, for example distance from the river, lithology, rainfall, land use/ land cover (LULC), soil type, stream power index, topographic wetness index, rainfall, slope, morphometric parameters of the catchment and also socioeconomic impacts of flooding. The factors are chosen depends on expert's view on the natural processes and having regard environmental properties of the research area, interaction between natural components and morphometric features of the drainage basin. One of the main question in flood investigation is which factors have significant influence on flood occurrences and flood parameters and how to determine the weights of each factor. Other important question considered in the literature is about the meaning of the main concepts: flood susceptibility, vulnerability, hazard and risk. Often susceptibility and vulnerability are used with the same meaning though the susceptibility is considered as a possibility that the event could be happen and the vulnerability is the sensitivity degree toward a natural hazard, associated to the exposure to a catastrophic event and combined with the human ability to resist. Flood hazard is associated with the probability of a flood event. According to the Directive 2007/60/EC on the assessment and management of flood risks "flood risk" means the combination of the probability of a flood event and of the potential adverse consequences for human health, the environment, cultural heritage and economic activity.

There are many qualitative and quantitative methods for the flood vulnerability assessment. However, it is necessary to point out, that the assessment of the flood vulnerability is done under the subjective and uncertain conditions (for example, there are short records or only few measured points) [8]. The fuzzy logic approach is an appropriate tool for flood vulnerability assessment [9]. This approach provides adequate processing the expert knowledge and uncertain quantitative data $[10,11]$. The fuzzy logic, implemented in GIS environment is used as an overlay technique when there are inaccuracies in attribute and in the geometry of spatial data [12-15].

The aim of the current research is to show the advantages of the fuzzy logic approach and geographic information systems (GIS) in assessment of flood vulnerability and to build a GIS data base to be used in decision making for flood vulnerability / flood hazard management. The flood vulnerability map will be elaborated in GIS environment using multi-criteria analysis and fuzzy logic. Precipitation, distance from streams, flow accumulation, lithology, land use, slopes and altitude will be considered and analysed as factors influencing the floods. 


\section{Data and Methodology}

The flood assessment and flood vulnerability map of the river basin are done in GIS environment (ArcGIS, ESRI Inc.). ArcGIS Spatial analyst tools - Overlay is used for determining areas prone to floods in different rate. Data about relief, precipitation, lithology, drainage network and LULC is used for that purpose. The analysis is made for the whole river basin. Using the basin approach is the most logical approach in flood assessment because all hydrological and geological-geomorphological components of the area strongly interact in the frame of the catchment.

In this study, the flood vulnerability model is constructed through following two main etaps:

- Determining the river catchment area

- Determining the factors with significant influence of the floods

\subsection{Determining the River Catchment Area}

The drainage network and watershed are delineated on the base of ASTER GDEM (a product of METI and NASA) with 30 m horizontal resolution using Hydrology tool of ArcGIS Spatial analyst and following the sequence: Quality of data raster; Project raster; Filling sinks and removing inaccuracies; Flow direction; Basin; Flow accumulation; Stream raster.

Stream raster is calculated applying Map algebra (ArcGIS Spatial Analyst Tools) on flow accumulation raster. The main question in stream raster generation is: what is the threshold value of the area from which a stream could be formed. The value could be different depends on the relief of the area and the factors of erosion. The horizontal resolution of the digital elevation model (DEM) has also to be taken into account. All cells with a value less than the determined threshold value receive a value 0 (they don't form a stream) and others 1 (there is a stream).

\subsection{Determining the Factors with Significant Influence of the Floods}

Having regard the researches published in this field there are many factors that could cause the floods. Floods are complex natural phenomena depending on hydrological, geological-geomorphological, soils and land use / land cover peculiarities.

Taking into account the specific features of the research geographical area and limited available data, the following seven parameters are considered as main flood influencing factors: rainfall intensity, flow accumulation, distance from stream, lithology, LULC, slope and altitude.

Rainfall intensity. Rainfall and particularly intensive rainfall have a major role for flood occurrence. An intensive rain even for a short time can cause floods more that light rain during several days. Of course, the time for drainage of surface water is in the relation of the form of the river basin, stream density, soil/rock permeability and vegetation. The rainfall intensity is presented by modified Fournier index (MFI), calculated 
as the sum of monthly average amount of precipitation divided to the average annual amount of precipitation [16].

Flow accumulation. It is an indicator for the water quantity of the area. Flow accumulation is determined on the base of the DEM and presents the accumulated flow in each cell of the raster. The value of the cell shows the number of the cells from which the flow is accumulated. If the flow accumulation is 0 then there is no runoff. The runoff is increased at greater values of flow accumulation.

Distance from stream. The distance from streams as a flood factor should be assessed in relation to the possibility the high waters to flood adjacent areas and to the time for which the surface (slope) flows reach the riverbeds.

Lithology. The rocks composition, their grain-size and physical properties determine the rocks permeability, which is of great importance for flood occurrences. High permeable rocks favor water infiltration and ground flow while less permeable rocks favor surface flow and at horizontal or low slope areas are factors for high flood vulnerability.

LULC. The type of land cover influences the time to drain the slope runoff. Forests favor the infiltration of rainwater in soils and prevent fast surface runoff. In this way, they decrease the probability of floods. Arable lands, grasslands and sparsely vegetated areas have less hydrological role and could favor floods occurrence in case of appropriate topographic conditions and intensive rains.

Slope and altitude. The altitude and slope of the catchment area determine the hydroclimatic conditions. Usually high elevated areas have more precipitation which is a prerequisite for higher river runoff, but on the other side valleys and lowlands (with altitude less than $200 \mathrm{~m}$ ) are more prone to floods because they facilitate the river overflow in case of high water. The elevation and slope influence on the most of cases on the speed of the water flow and development of erosion processes. It is need to point that the prerequisites for floods are more in cases of low and flat areas in comparison with the elevated areas with high slope .

\section{$3 \quad$ Fuzzy Logic Overlay Analysis}

The concept of the fuzzy logic is proposed by Zadeh in 1965 [17]. It is developed around the basic idea of so-called fuzzy sets or membership function. Fuzzy set theory is regarded as an extension of classical set theory. It enables the processing of imprecise information by means of membership functions, in contrast to Boolean transformations. Usually the membership functions is assigned 0 to false values and 1 to true ones, but fuzzy logic also allows in-between values [10]. 
Here, the main idea is to assess the flood vulnerability by applying fuzzy logic in respect to the several flood factors. As a result, a flood vulnerability map is created in GIS environment.

According proposed methodology the fuzzy logic overlay is applied in GIS environment each one of flood factors is entered in GIS database as a separate layer. All vector layers (rainfall intensity, lithology, LCLU, etc.) are converted in raster surfaces. The next step is to create fuzzy membership raster at which the input raster is transformed a 0 to 1 scale, indicating the strength of a membership in a set, based on a specified fuzzification functions. These functions are applied to the initially created rasters for rainfall intensity, distance from streams, flow accumulation, slope and altitude. For lithology and LULC which present qualitative information (not quantitative) the reclassified rasters (values from 1 to 5 according to the susceptibility of floods) are used as membership input rasters. A reclassified distance from stream raster (rates from 1 to 5) is also used to create a membership raster. The applied membership type for slope and altitude is "small" and for the other factors we applied "large" taking into account the nature of the modelled feature and spatial distribution of the values. After creating fuzzy membership layers a fuzzy overlay is applied. The values of the resulted flood vulnerability, presented in the output raster, are classified in 5 classes ( 1 very low vulnerability to 5 - very high vulnerability) using natural breaks classification method.

\subsection{Case Study: The River Luda Kamchia Basin}

The above described methodology is applied for the river Luda Kamchia basin. It is situated in the Eastern Bulgaria and is a part of the river Kamchia basin (see Error!

\section{Reference source not found.)}

The river Kamchia is the largest Bulgarian river which flows into the Black Sea. The study area is about $1600 \mathrm{~km} 2$. The form of the basin is long and narrow, and it is a bit larger in the low part which could be a prerequisite for floods in the low part of the river basin. The relief is predominantly low-mountainous $(600-1000 \mathrm{~m}$ above sea level) and includes Kotlenska, Varbishka and Karnobatska mountains. The highest point of the watershed is peak Bulgarka $(1181 \mathrm{~m})$. About the lithology the most part of the river basin is built of alternation of carbonate and non-carbonate rocks. The drainage network of the river Luda Kamchia catchment is well developed. The streams density is about 1 $-1.5 \mathrm{~km} / \mathrm{km} 2$ and it increases to $2 \mathrm{~km} / \mathrm{km} 2$ in the western higher part of the study area. The annual amount of precipitation is about 600 to $800 \mathrm{~mm}$. The maximum is observed in May - June and November - December. Forests cover about $88 \%$ of the total area of the river basin. Non-irrigated arable land takes nearly $4 \%$ of the area and other types of land use are less than $2 \%$ each of the river basin. Settlements have $0.45 \%$ of the investigated area. In this relation forests are the land use/land cover type with the highest influence for runoff and water quantity of the catchment. 


\subsection{Flood Factors for River Luda Kamchia Basin}

Rainfall intensity. In the current research the precipitation data for 30 years period is taken from precipitation reference book, published by Bulgarian National Institute of Meteorology and Hydrology. There are only 4 meteorological stations in the river Luda Kamchia basin and other 5 stations, located near to the investigated area are also used in the analysis. The spatial distribution of the MFI is done by inverse distance weighted (IDW) interpolation. The results show not very high intensity of rainfall. The values of the MFI are between 50.64 and 70.12. In this case we reclassified the output raster in 3 classes using natural breaks classification method: 1 - with very low importance for flood occurrence; 2 - low and 3 - moderate.

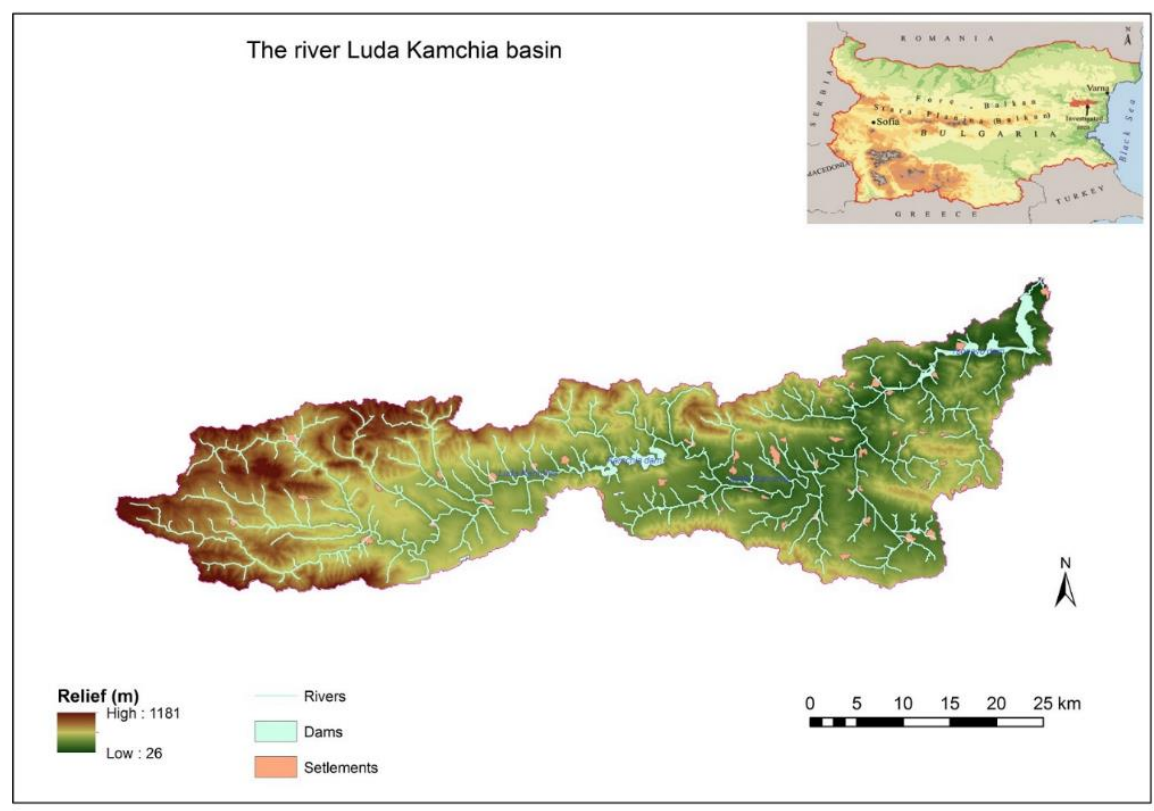

Fig. 1. A Case study: The River Luda Kamchia Basin.

Flow accumulation. The flow accumulation map is elaborated on the base of digital elevation model (see Error! Reference source not found.). The values of flow accumulation in the generated raster for the river Luda Kamchia basin are from 0 to 2294 333. Taking into account the relief of the catchment it is considered that the threshold area to create a stream is $5 \mathrm{~km}^{2}$. The number of cells corresponding to this area at $30 \mathrm{~m}$ DEM resolution is 5556. In this case the new stream raster includes cells with value greater than 5556. After checking the results, reviewing the surface and making tests with different values of the pixels it is accepted 2500 as a threshold value to be able to include also smaller lines with temporal flow. In this regard and taking into account natural breaks it is reclassified the flow accumulation raster from 1 to 5 
where all cells with value less than 25700 received value of 1 (very small importance for flood occurrences) and these with value great than 1700300 received value 5 (very high importance for flood occurrence). The values between 25700 and 1700300 are divided in 3 classes (with rates 2, 3 and 4) using natural breaks method.

Distance from streams. Five flood vulnerability intervals are set according to the Table 1 . The stream density and the type of the relief are taken into account in determining the distance from streams as a flood factor. The distance zones are determined using ArcGIS Analysis Tools - Proximity - Multiple Ring Buffer and evaluated to the flood vulnerability. The values of 1 to 5 are added to the generated polygons to show the vulnerability of each polygon to floods.

Table 1. Flood vulnerability according to the distance from stream

\begin{tabular}{ll}
\hline Distance from stream $(\mathrm{m})$ & Flood vulnerability \\
\hline $0-50$ & 5 - very high \\
$50-150$ & 4 - high \\
$150-300$ & 3 - moderate \\
$300-500$ & $2-$ low \\
more than 500 & 1 - very low \\
\hline
\end{tabular}

Lithology. The information about the lithology is taken from the geological map, scale 1:200000 and is entered in the GIS environment as a polygon layer. Having regard the physical-mechanical properties and chemical composition of the rocks they are divided into 5 groups: unconsolidated non-carbonate rocks; consolidated carbonate rocks; consolidated non-carbonate rocks; alternation of carbonate and non-carbonate rocks; volcanic rocks [18]. These groups are rated to flood vulnerability as follow (see Table 2).

Table 2. Flood vulnerability determined by lithology

\begin{tabular}{ll}
\hline Rocks & Flood vulnerability \\
\hline Unconsolidated non-carbonate rocks & $4-$ high \\
Consolidated carbonate rocks & $2-$ low \\
Consolidated non-carbonate rocks & $5-$ very high \\
Alternation of carbonate and non-carbonate rocks & $4-$ high \\
Volcanic rocks & $4-$ high \\
\hline
\end{tabular}

Unconsolidated non-carbonate rocks (gravel and sand) are accumulated in the lower part of the river valleys. Though the high permeability of sand they have high flood vulnerability rate because of the high level of ground water. The gorge nature of Luda Kamchia River is a reason for weak accumulation and limited distribution of the alluvial deposits in this part of the catchment area. Consolidated carbonate rocks (limestones, dolomites, sandy and marlly limestones) have limited distribution in the river Luda Kamchia basin, mainly in Kotlenska mountain (the Northern high part of the 
catchment) and in some areas to the East, in the low part of the river basin. Karst relief could be a prerequisite for flash floods but having regard the morphometric properties of the river basin and limited area of these rocks they are rated as low flood susceptibility. Consolidated non-carbonate rocks are presented by clay-sandy slates, sandstones, conglomerates and clays, and they are a good condition for surface runoff. These rocks are slightly spread in the Luda Kamchia River catchment. Larger areas could be found in the low part of the basin after the Kamchia dam. A considerable part of the river Luda Kamchia catchment is built by alternations of carbonate and non-carbonate rocks (slates and sandy limestones, clayey marls and limestones, clayey-sandy slates). Volcanic rocks are presented by tuffs and andesites. They have limited distribution at southern slopes of Kamchiiska Mountain, the low part of the drainage basin.

LULC. The information about the LULC types in the catchment of the river Luda Kamchia are given in Table 3. The types are determined by CORINE Land Cover 2012 project. The largest area of the basin is covered by forests take (about 88\%). This fact significantly decreases the vulnerability to floods. Arable lands, vineyards, pastures and shrubs which are not big obstacle for surface runoff and could facilitate floods have around $6 \%$ of the area. The sparsely vegetated areas which are rated as high vulnerability to floods areas takes less than $1 \%$ of the investigated basin. Urban areas, industrial sites are not taken into evaluation because of the scale of the research and lack of information about the infrastructure. Water bodies (dams) also are not evaluated.

Table 3. LULC flood vulnerability

\begin{tabular}{ll}
\hline LULC & Flood vulnerability \\
\hline Urban areas & Not evaluated \\
Industrial or commercial units & Not evaluated \\
Mineral extraction sites & Not evaluated \\
Sport and leisure facilities & Not evaluated \\
Non-irrigated arable land & 3 - moderate \\
Vineyards & 3 - moderate \\
Fruit trees and berry plantations & 2 - low \\
Pastures & 3 - moderate \\
Complex cultivation patterns & 3 - moderate \\
Land principally occupied by agriculture & \\
with significant areas of natural vegetation & 3 - moderate \\
Broad-leaved forest & 1 - very low \\
Coniferous forest & 2 - low \\
Mixed forest & 1 - very low \\
Natural grassland & 3 - moderate \\
Transitional woodland/shrub & 3 - moderate \\
Sparsely vegetated areas & 4 - high \\
Water bodies & Not evaluated \\
\hline
\end{tabular}


Slope. The slopes are calculated in ArcGIS on the base of DEM. For the most of the catchment of the river Luda Kamchia they are in the interval 3-10 degree followed by 0 - 3 degree. Steep areas 25 - 44 degree take a limited part of the basin. Five slope intervals are determined having regard the morphometric features of the river basin and rated to flood vulnerability (see Table 4).

Table 4. Flood vulnerability determined by slopes

\begin{tabular}{ll}
\hline Slopes in degree & Flood vulnerability \\
\hline $0-3$ & 5 - very high \\
$3-10$ & 4 - high \\
$10-18$ & 3 - moderate \\
$18-25$ & 2 - low \\
$25-44$ & 1 - very low \\
\hline
\end{tabular}

Altitude. The relief of the river Luda Kamchia basin is predominantly low mountainous. The highest point is $1181 \mathrm{~m}$. The altitude zone of 200 to $600 \mathrm{~m}$ is $65 \%$ of the whole basin. The areas elevated above $1000 \mathrm{~m}$ are nearly $0.55 \%$. The hilly lands favor fast surface runoff to the river beds and could be considered as areas with high to moderate vulnerability to floods. In this regard and taking into account the relief of the area we determined 5 altitude intervals rated to the flood vulnerability (see Table 5).

Table 5. Flood vulnerability determined by altitude

\begin{tabular}{ll}
\hline Altitude $(\mathrm{m})$ & Flood vulnerability \\
\hline$<100$ & 5 - very high \\
$100-200$ & $4-$ high \\
$200-600$ & 3 - moderate \\
$600-1000$ & $2-$ low \\
$>1000$ & $1-$ very low \\
\hline
\end{tabular}

\subsection{Results and Flood Vulnerability Map}

Application of fuzzy logic overlay analysis allows to consider the combined effect of flood factors. As a result a flood vulnerability map is created (see Figure 2). The fuzzy logic overlay analysis shows moderate flood vulnerability in the predominant areas of the river basin. The values of the flood vulnerability rate are a bit higher in the low part of the river basin and also in the central part, at the drainage area of right tributary of the river Luda Kamchia, after Kamchia dam. This is related with the horizontal topographic surface (slope between $0^{\circ}$ and $3^{\circ}$ ) and also with the physical properties of the rocks - consolidated non-carbonate rocks. The high flood vulnerabiity on the limited 
part of the slopes of Kotlenska mountain (western part of the river basin) could be explained mainly with the higher rainfall intensity and lithology presented by alternation of carbonate and non-carbonate rocks. Applying fuzzy logic overlay shows in generally higher flood susceptibility near to the river beds. The form of the river basin, which is narrow at the central part and wider in the low part is a prerequisite for accumulation of higher water quantity in the low part of the river basin which could cause floods.

The results about the flood susceptibility in the river Luda Kamchia catchment are subject of future investigation. More attention should be given to the removing data imperfection and interpreting the results of the analysis of flood influencing factors. The number of factors is not limited and additional factors could be considered too. The built GIS data base is open and other information could be entered. About the flood cases in the past periods the published data is not enough and it does not present the time and spatial characteristics of this nature phenomenon. The analysis of the flood influencing factors show that they could facilitate flood occurrence. The questionnaires about floods in the river Luda Kamchia basin show the floods happen often in the valley of the river Luda Kamchia. The lack of the published data about big floods in the investigated area could be explained with the geomorphological features of the river basin which are not favorable for wide floods and also with the experience of the local people to organise their activity out of the risk zones.

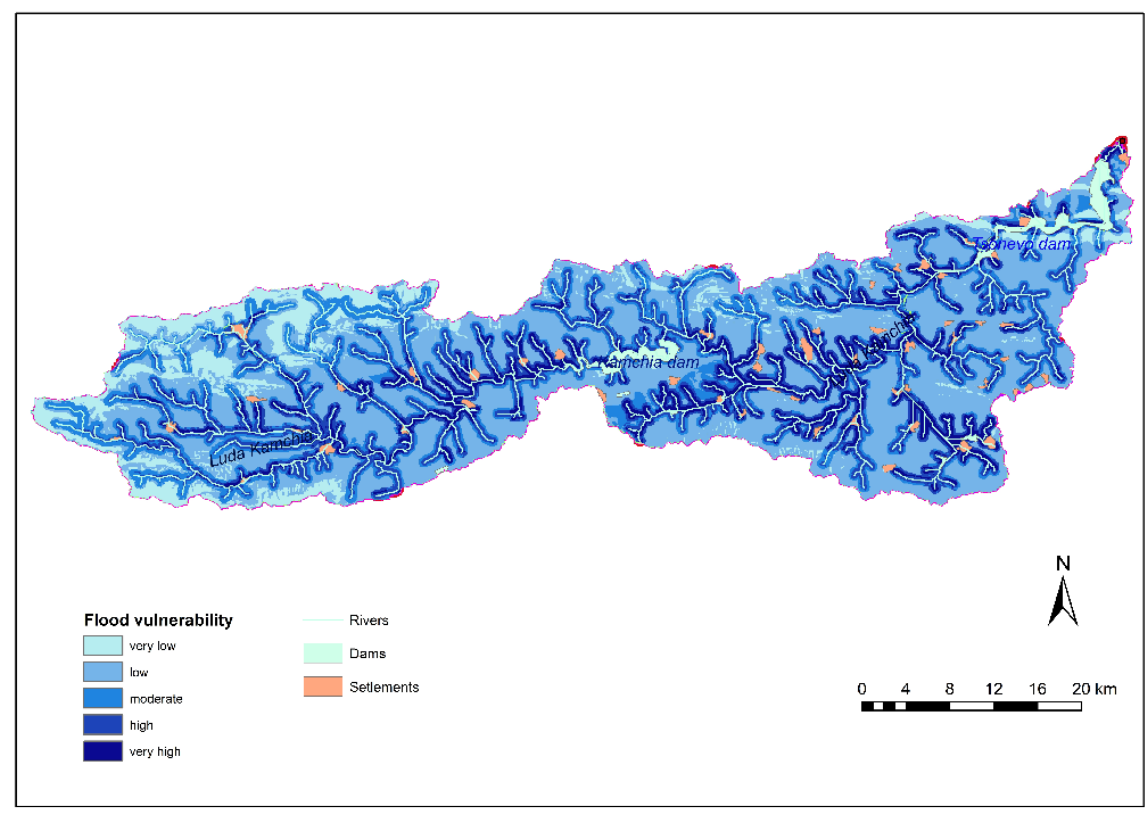

Fig. 2. Flood vulnerability map using fuzzy logic overlay. 


\section{Conclusions}

The river flood vulnerability map created by fuzzy logic overlay analysis shows that the river Luda Kamchia basin is not under the great threat of floods though there are different segments of the river valleys with high flood vulnerability. In this regard the flood influencing factors should be taken into account in regional development and planning. The both big dams (Kamchia, in the central part of the basin and Tsonevo, in the low part of the river basin) control the river runoff and decrease the risk of floods but have to be properly managed. More attention should be given to the determining of flood factors and their weights, taking into account their importance for flood occurrences and interaction between different factors.

Application of GIS technology allows processing of a large amount of data and optimizing the decision making. The built GIS data base includes information about drainage network, river basin boundary, relief, slopes, lithology, precipitation, flow accumulation and LULC. The system is open and could be completed with other environmental and economic features that effect on the foods.

The assessment of river flood vulnerability and elaboration of maps of flood vulnerability by fuzzy logic overlay analysis is a first step in development of the information system for integrated risk assessment from natural disasters.

\section{Acknowledgement}

The authors express their gratitude to the Bulgarian National Science Fund for the partial financial support under the Grant № DFNI - I02/15 from 12.12.2014, titled "Information System for Integrated Risk Assessment from Natural Disasters".

\section{References}

1. Kazakis, N., Kougias, I., Patsialis, T.: Assessment of flood hazard areas at a regional scale using an index-based approach and analytical hierarchy process: Application in RhodopeEvros region, Greece. Science of the Total Environment 538, 555-563 (2015).

2. Kourgialas, N., Karatzas G.: Flood management and a GIS modelling method to assess flood-hazard areas - a case study. Hydrological Sciences Journal 56(2), 212-225 (2011).

3. Kundu, A., Kundu, S.: Flood vulnerability assessment using participatory GIS approach. Journal of Remote Sensing \& GIS 2 (1), 8-22 (2011).

4. Kafira V., Albanakis K., Oikonomidis D.: Flood susceptibility assessment using G.I.S. An example from Kassandra peninsula, Halkidiki, Greece. In: Proceedings on 10th International Congress of the Hellenic Geographical Society, Thessaloniki, Greece (2014).

5. Wang, Y.: Using Landsat 7 TM data acquired days after a flood event to delineate the maximum flood extent on a coastal floodplain. Int. J. Remote Sens. 25, 959-974 (2004).

6. Lacava, T., Filizzola, C., Pergola, N., Sannazzaro, F., Tramutoli, V.: Improving flood monitoring by the Robust AVHRR Technique (RAT) approach: The case of the April 2000 Hungary flood. Int. J. Remote Sens. 31, 2043-2062 (2010). 
7. Mallinis, G., Gitas, I.Z., Giannakopoulos, V., Maris, F., Tsakiri-Strati, M.: An object-based approach for flood area delineation in a transboundary area using ENVISAT ASAR and LANDSAT TM data. Int. J. Digit. Earth 6, 1-13 (2013).

8. Papaioannou, G., Vasiliades, L., Loukas, A.: Multi-criteria analysis Framework for potential flood prone areas mapping. Water Resour Manage 29, 399-418 (2015).

9. Yeganeh N., Sabri, S.: Flood vulnerability assessment in Iskandar Malaysia using multicriteria evaluation and fuzzy logic. Research Journal of Applied Sciences, Engineering and Technology 8(16), 1794-1806 (2014).

10. Zimmerman, H.: Fuzzy set theory and it applications. Kluwer Academic Publishers, Norwell MA, USA (1996).

11. Zlateva, P., Velev, V.: Complex risk analysis of natural hazards through fuzzy logic. Journal of Advanced Management Science 1 (4), 395-400 (2013).

12. Leonardi, G., Palamara, R., Cirianni, F.: Landslide susceptibility mapping using a fuzzy approach. Procedia Engineering 161, 380-387 (2016).

13. Jiang, W., Deng, L., Chen, L., Wu, J., Li, J.: Risk assessment and validation of flood disaster based on fuzzy mathematics. Progress in Natural Science 19, 1419-1425 (2009).

14. Fotis, M., Georgia V., Apostolos, V.: Estimation of the prefecture of Evros vulnerability in flood cases using GIS and fuzzy set algebra. In: Proceedings on Sixteenth International Water Technology Conference, IWTC 16, Istanbul, Turkey (2012).

15. Perera, E., Lahat, L.: Fuzzy logic based flood forecasting model for the Kelantan River basin, Malaysia. Journal of Hydro-environment Research 9, 542-553 (2015).

16. Arnoldus, H.: An approximation of rainfall factor in the universal soil loss equation. Assessment of erosion, Boodt, M. \& Gabriels, D. eds., Wiley, Chichester, U.K., 127-132 (1980).

17. Zadeh, L.: Fuzzy sets. Information and Control 8, 338-353 (1965).

18. Nikolova, V.: Determining of the morpholithology yypes in the Kamchia River Basin (Eastern Bulgaria) by means of Geographic Information System (GIS). Geographica Pannonica 14 (3), 76-82 (2010). 